除虫菊の有効成分定量に關する䂰究(笴9 郝)

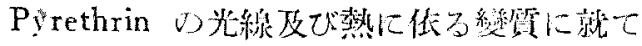

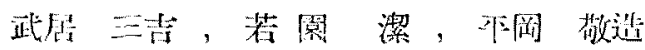

(京都帝國大學化學佃斻所)

昭和16 年5月6日曼理

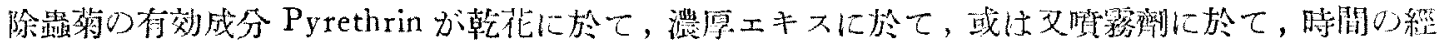

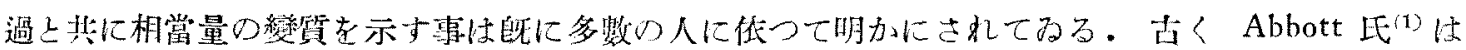

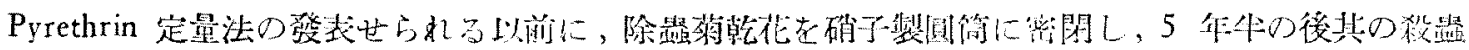

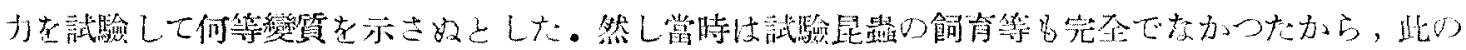

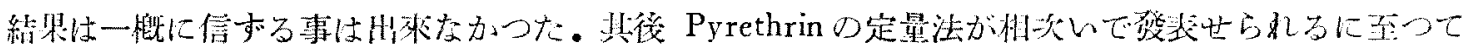

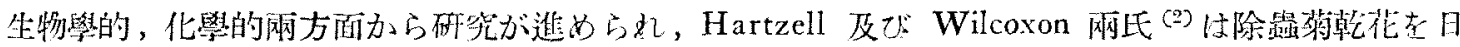

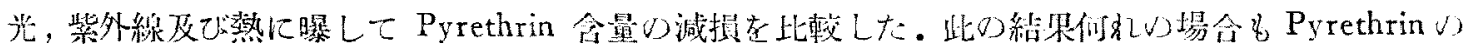

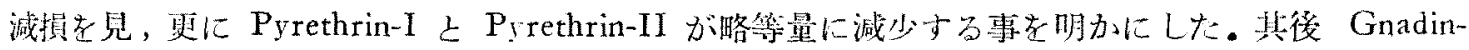

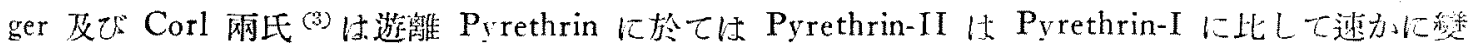
筫娍提すると述べて居る。

之等 Pyrethrin の減損に就いて，Gnadinger 及び Corl 网纸或は Tattersfield 及び Martin 网

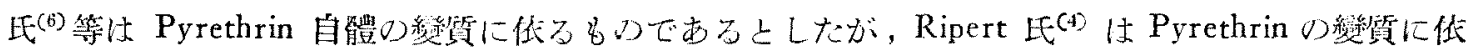

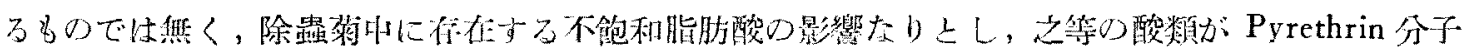

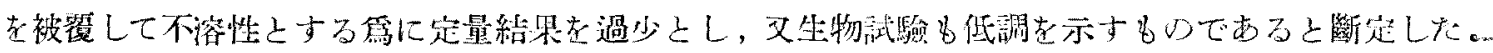

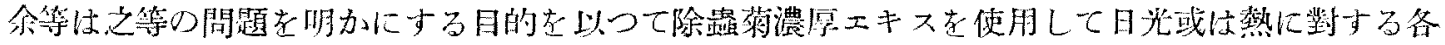

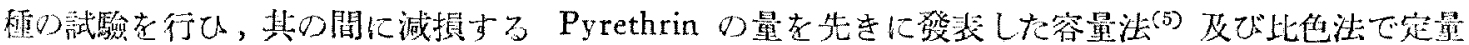

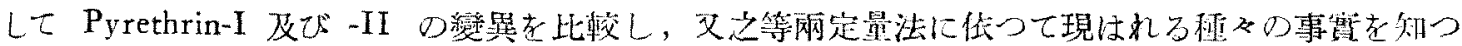
たので以下に報告する炏第する。

\title{
實駼
}

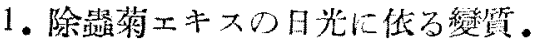

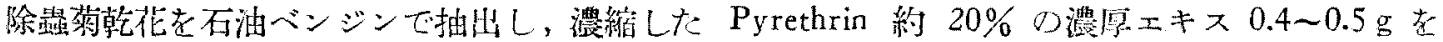

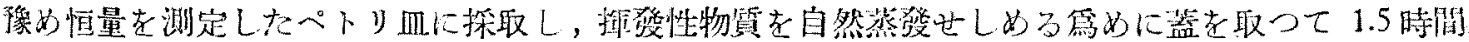

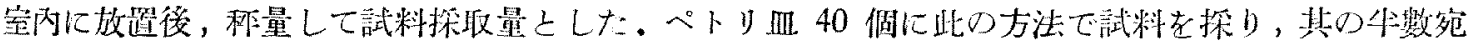
在以つて道射日光に依る變筫及び輻射日光に依る變筫を見た。

A. 直射日光几依る變質。

上記試料を昭和 15 年 5 月上旬から 7 月上旬に至る 60 日間賞研労所の居上に放通して，其り周

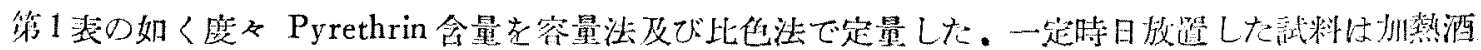

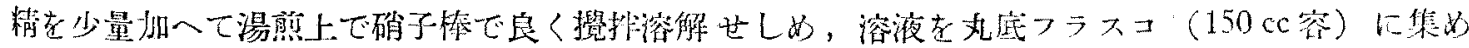

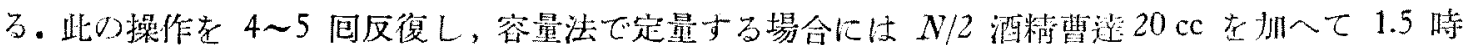
間加水分解し，終了後酒精を溜去して徭，常法に準じて操作老進めた。比色法で定量するには加熱 


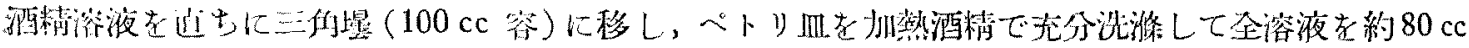

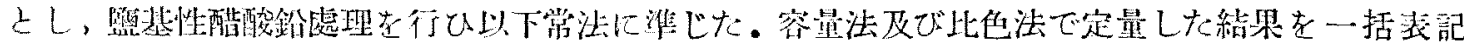
ナイば次け如くなる。

第 1 褧

\begin{tabular}{|c|c|c|c|c|c|c|}
\hline \multirow{3}{*}{ 放置日数 } & \multirow{2}{*}{\multicolumn{2}{|c|}{$\begin{array}{c}\text { 容 } \\
\text { Pyrethrin-I }\end{array}$}} & \multicolumn{2}{|c|}{ 法 } & 比 & 法 \\
\hline & & & & in-II & \multicolumn{2}{|c|}{ Pyrethrins } \\
\hline & $(\%)$ & 減强 $(\rho \circ)$ & $(\%)$ & 減損 $(96)$ & $(\%)$ & 減損 $(\%)$ \\
\hline 0 & 8.88 & 0 & 12.86 & 0 & 20.38 & 0 \\
\hline 5 & 8.60 & 2.25 & 12.33 & 4.21 & 18.42 & 9.61 \\
\hline 10 & 7.50 & 15.54 & 12.93 & -0.54 & 16.28 & 20.12 \\
\hline 20 & 6.84 & 22.97 & 12.83 & 0.31 & 15.17 & 25.56 \\
\hline 30 & 5.91 & 33.44 & 11.43 & 11.12 & 12.62 & 38.07 \\
\hline 40 & 4.78 & 46.17 & 11.15 & 13.29 & 11.00 & 46.02 \\
\hline 50 & 4.10 & 53.83 & 11.11 & 13.61 & 10.29 & 49.51 \\
\hline 60 & 3.40 & 61.71 & 10.91 & 15.16 & 9.11 & 55.29 \\
\hline
\end{tabular}

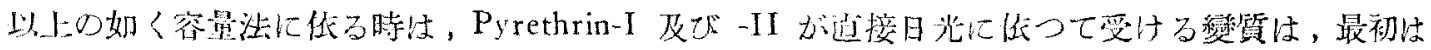

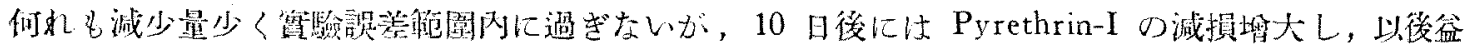

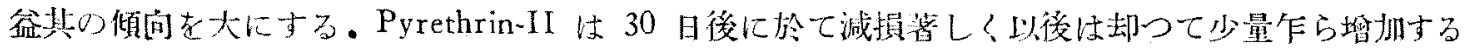

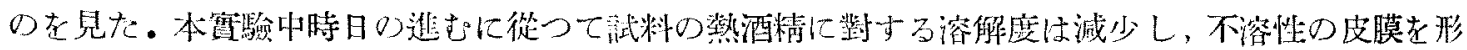

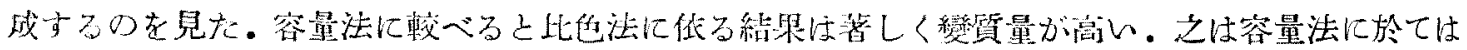

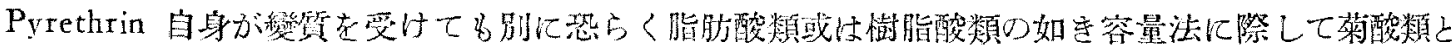

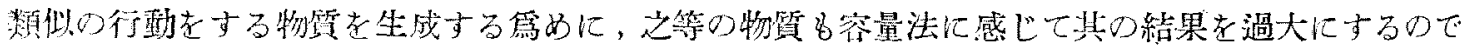

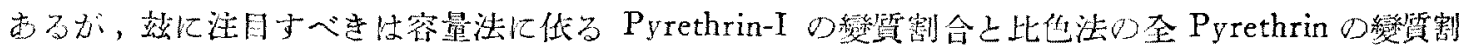

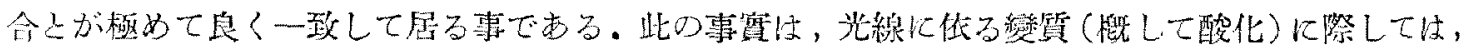

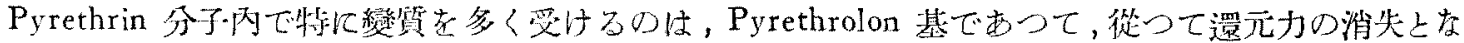

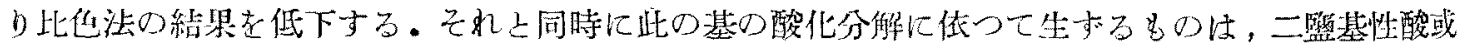
はOxy 酸乃至は Keton 酸等であつて们れも第二勿酸に極めて類似の行動在探る酸である事山想

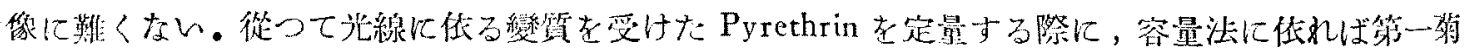

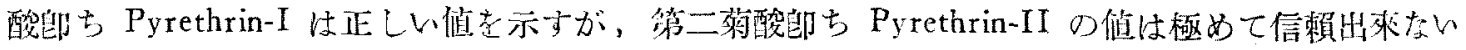

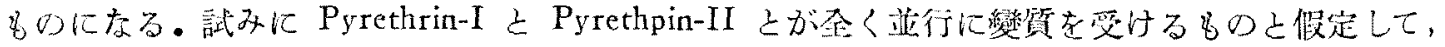

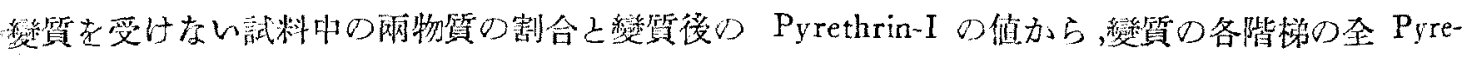

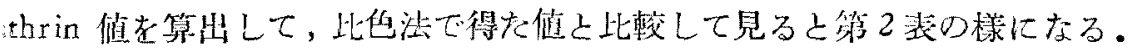


第 2 张

\begin{tabular}{|c|c|c|c|c|c|}
\hline \multirow{2}{*}{ 放 量 } & \multirow{2}{*}{ 日 數 } & \multicolumn{2}{|c|}{ 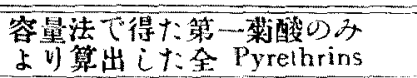 } & \multicolumn{2}{|c|}{ 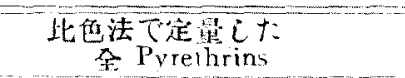 } \\
\hline & & $(\%)$ & 減 損 $(\%)$ & $(\%)$ & 減損 $(\%)$ \\
\hline & 0 & 21.74 & 0 & 20.38 & 0 \\
\hline & 5 & 21.07 & 3.08 & 18.42 & 9.61 \\
\hline & 10 & 18.37 & 15.50 & 16.28 & 20.12 \\
\hline & 20 & 16.76 & 22.91 & 15.17 & 25.56 \\
\hline & 30 & 14.48 & 33.39 & 12.62 & 38.07 \\
\hline & 40 & 11.71 & 46.13 & 11.00 & 46.02 \\
\hline & 50 & 10.04 & 53.81 & 10.29 & 49.51 \\
\hline & 60 & 8.33 & 61.68 & 9.11 & 55.29 \\
\hline
\end{tabular}

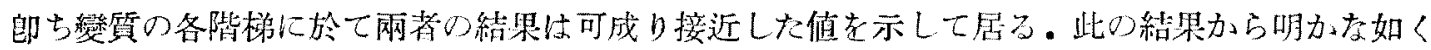

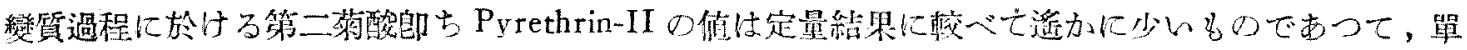

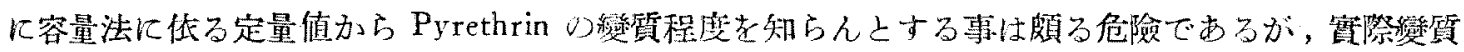
を來たしてみる試料中の Pyrethrin-I 及び -II の割合はーI に比して -II が非常に高いから直ち に之童知る事が出來る。

B. 間接日光に依る䌨資

以上は直射日光を受けた場合の變資走示したものであるが，進接日光老受け室內に於ても相常

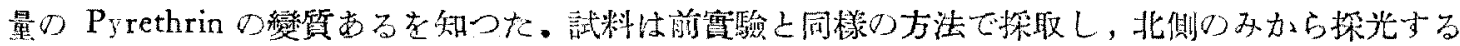

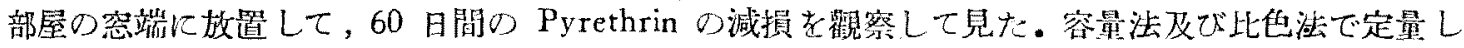
た絬果を一括表記すれば第了表に示与如くである。

第 3 表

\begin{tabular}{|c|c|c|c|c|c|c|}
\hline \multirow{3}{*}{ 放置 } & \multirow{2}{*}{\multicolumn{2}{|c|}{$\frac{\text { 容 }}{\text { Pyrethrin-I }}$}} & \multicolumn{2}{|c|}{ 法 } & \multirow{2}{*}{\multicolumn{2}{|c|}{$\frac{\text { 比 色 }}{\text { Pyrethrins }}$}} \\
\hline & & & & in-1I & & \\
\hline & $(\%)$ & 減損 （\%) & $(\%)$ & 滅损 (\%) & $(\%)$ & 隇損 $\quad \%)$ \\
\hline 0 & 8.88 & 0 & 12.86 & 0 & 20.38 & 0 \\
\hline 5 & 8.56 & 3.60 & 12.41 & 3.50 & 20.28 & 0.49 \\
\hline 10 & 8.76 & 1.35 & 12.34 & 4.04 & 18.99 & 6.82 \\
\hline 20 & 8.56 & 3.60 & 12.32 & 4.20 & 18.17 & 10.84 \\
\hline 30 & 6.83 & 22.86 & 12.41 & 3.50 & 17.00 & 11.58 \\
\hline 40 & 5.78 & 34.91 & 12.66 & 1.55 & 16.52 & 18.94 \\
\hline 50 & 5.63 & 36.59 & 12.55 & 2.41 & 15.57 & 23.60 \\
\hline 60 & 5.56 & 37.39 & 11.74 & 8.71 & 14.31 & 29.78 \\
\hline
\end{tabular}

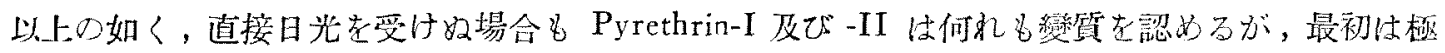

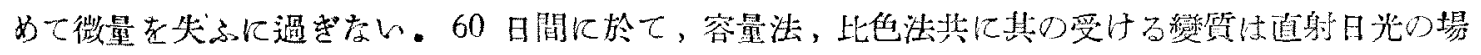

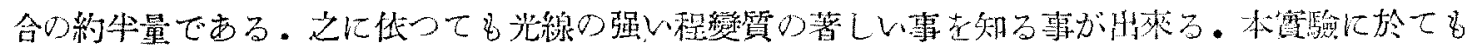

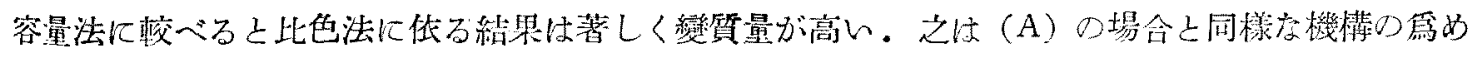

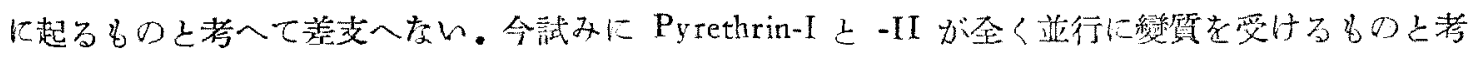




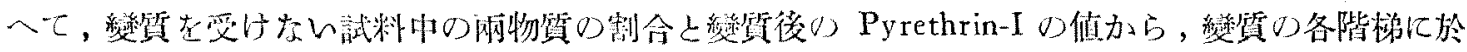

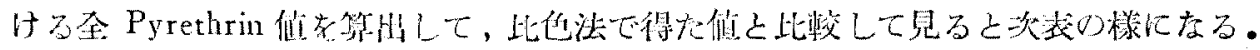

\begin{tabular}{|c|c|c|c|c|c|}
\hline \multirow{2}{*}{ 放置日数 } & \multicolumn{2}{|c|}{ 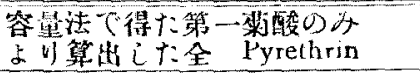 } & \multicolumn{3}{|c|}{ 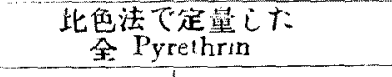 } \\
\hline & $(\%)$ & 減 損 $(\%)$ & $(\%)$ & 娍 & 損 $(\%)$ \\
\hline 0 & 21.74 & 0 & 2038 & & 0 \\
\hline 5 & 20.97 & 3.54 & 20.28 & & 0.49 \\
\hline 10 & 21.46 & 1.28 & 18.99 & & 6.82 \\
\hline 20 & 20.97 & 3.54 & 18.17 & & 10.84 \\
\hline 30 & 16.73 & 23.04 & 17.00 & & 11.58 \\
\hline 40 & 14.16 & 34.86 & 16.52 & & 18.94 \\
\hline 50 & 13.79 & 36.56 & 15.57 & & 23.60 \\
\hline 60 & 13.62 & 37.35 & 14.31 & & 29.78 \\
\hline
\end{tabular}

以上の栐に，Pyrethrin-I から算州して得た全 Pyrethrin 量と，比他法で定量した全 Pyrethrin

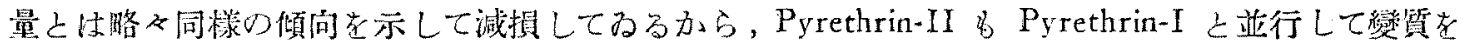

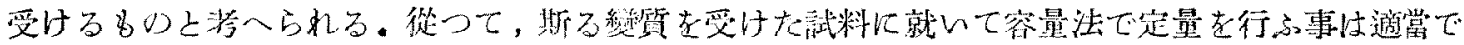
ない上言ふ事が弪來る。

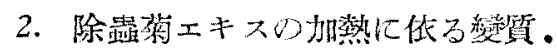

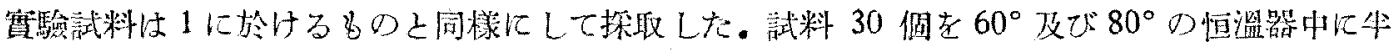

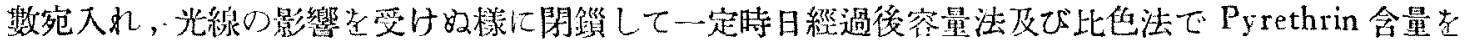
定量して，其の變質を比較した。

A. $80^{\circ}$ 加深に依る變質

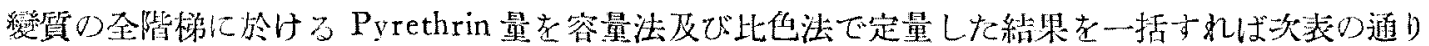
である。

\begin{tabular}{|c|c|c|c|c|c|c|}
\hline \multirow{3}{*}{$\begin{array}{l}\text { 放䠄 } \\
\text { 日期 }\end{array}$} & \multicolumn{2}{|c|}{ 签 } & \multicolumn{2}{|c|}{ 洼 } & 比 & 法 \\
\hline & \multicolumn{2}{|c|}{ Pyrethrin-I } & \multicolumn{2}{|c|}{ Pyrethrin-II } & \multicolumn{2}{|c|}{ Pyrethrins } \\
\hline & $(\%)$ & 滅捛 $(\%)$ & $(\%)$ & 減强 (\%) & $(\%)$ & 減損 $(\%)$ \\
\hline 0 & 10.00 & 0 & 13.72 & 0 & 21.43 & 0 \\
\hline 1 & 9.37 & 6.30 & 13.63 & 0.65 & 20.98 & 2.09 \\
\hline 3 & 9.40 & 6.00 & 13.51 & 1.53 & 20.83 & 2.80 \\
\hline 7 & 8.21 & 17.90 & 13.30 & 3.06 & 19.86 & 7.32 \\
\hline 14 & 7.02 & 29.80 & 14.39 & -4.88 & 18.68 & 12.82 \\
\hline 21 & 4.81 & 51.91 & 15.16 & -10.49 & 16.90 & 21.14 \\
\hline 28 & 3.16 & 68.40 & 15.98 & -16.47 & 16.22 & 24.31 \\
\hline
\end{tabular}

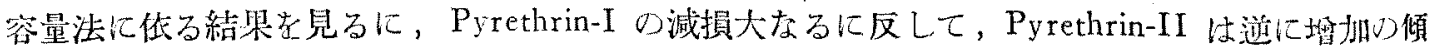

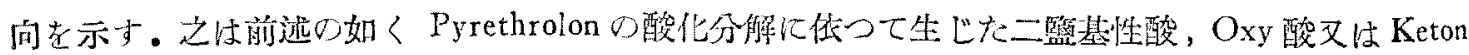




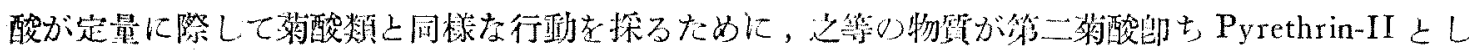

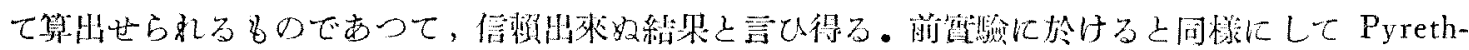

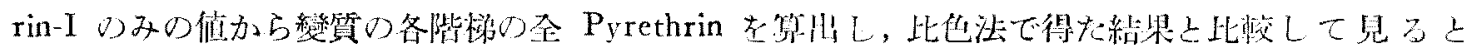
籍 6 袁の栐に左る。

\begin{tabular}{|c|c|c|c|c|}
\hline \multirow{2}{*}{ 故羁日嚾 } & \multicolumn{2}{|c|}{ 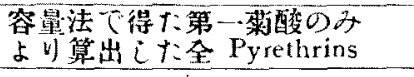 } & \multicolumn{2}{|c|}{$\begin{array}{c}\text { 比色法 } \\
\text { 全Pyrelhrins }\end{array}$} \\
\hline & $(\%)$ & 減 搷 $(\%)$ & $(\%)$ & 戚 招 (o) \\
\hline 0 & 23.72 & 0 & 21.43 & 0 \\
\hline 1 & 22.23 & 6.28 & 20.98 & 2.09 \\
\hline 3 & 22.30 & 5.99 & 20.83 & 2.80 \\
\hline 7 & 19.47 & 17.91 & 19.86 & 7.32 \\
\hline 14 & 16.65 & 29.81 & 18.68 & 12.83 \\
\hline 21 & 11.41 & 51.89 & 16.96 & 21.14 \\
\hline 28 & 8.56 & 63.91 & 16.22 & 24.31 \\
\hline
\end{tabular}

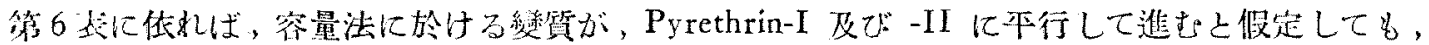

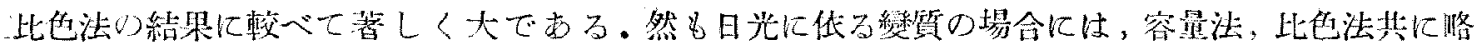

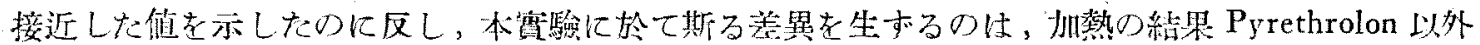

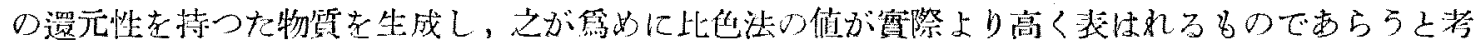
ヘられる。

B. $60^{\circ}$ 加熱に依乃称質

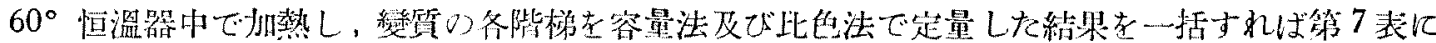
示す约くでする。

\begin{tabular}{|c|c|c|c|c|c|c|}
\hline \multirow{3}{*}{$\begin{array}{l}\text { 故置 } \\
\text { 日數 }\end{array}$} & & & \multicolumn{2}{|c|}{ 法 } & 比 & 法 \\
\hline & \multicolumn{2}{|c|}{ Pyrethrin-I } & \multicolumn{2}{|c|}{ Pyrethrin-II } & \multicolumn{2}{|c|}{ Pyrethrins } \\
\hline & $(\%)$ & 減捐 $(\%)$ & $(\%)$ & 減损 $(\%)$ & $(\%)$ & 減損 $(\%)$ \\
\hline 0 & 10.08 & 0 & 14.77 & 0 & 24.90 & 0 \\
\hline 1 & 9.03 & 10.41 & 14.37 & 2.71 & 23.21 & 6.79 \\
\hline 3 & 8.81 & 11.61 & 13.98 & 5.35 & 22.75 & 9.03 \\
\hline 7 & 7.79 & 22.72 & 13.56 & 8.19 & 22.34 & 10.28 \\
\hline 14 & 6.42 & 35.32 & 13.96 & 5.48 & 21.08 & 15.34 \\
\hline 21 & 5.52 & 45.24 & 15.01 & -1.62 & 20.25 & 18.67 \\
\hline 28 & 3.92 & 60.81 & 16.78 & -13.61 & 18.87 & 24.21 \\
\hline
\end{tabular}

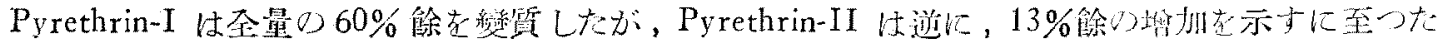

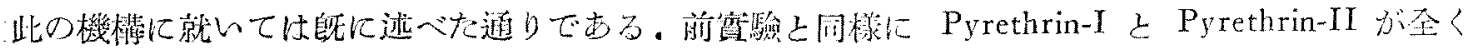

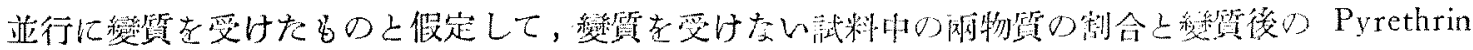

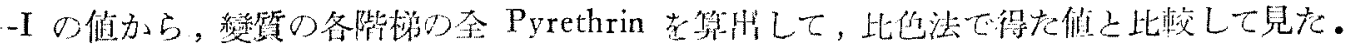




\begin{tabular}{|c|c|c|c|c|c|}
\hline \multirow{2}{*}{ 放置日数 } & \multicolumn{2}{|c|}{ 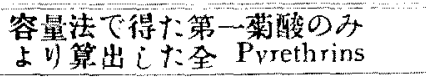 } & \multicolumn{3}{|c|}{$\begin{array}{l}\text { 比色法で定量した } \\
\text { 全Pyrehin }\end{array}$} \\
\hline & $(\%)$ & 減 损 (\%) & $(\%)$ & 減 & 损 $(\%)$ \\
\hline 0 & 24.85 & 0 & 24.90 & & 0 \\
\hline 1 & 22.26 & 10.42 & 23.21 & & 6.79 \\
\hline 3 & 21.71 & 12.63 & 22.75 & & 9.03 \\
\hline 7 & 19.20 & 22.74 & 22.34 & & 10.28 \\
\hline 14 & 15.82 & 36.34 & 21.08 & & 15.34 \\
\hline 21 & 13.60 & 45.27 & 20.25 & & 18.67 \\
\hline 28 & 9.66 & 61.12 & 18.87 & & 24.21 \\
\hline
\end{tabular}

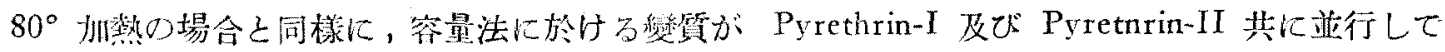

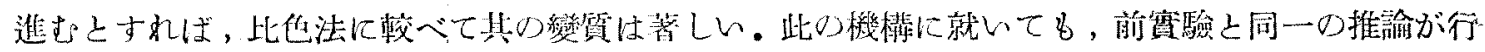
はれ得るものである。

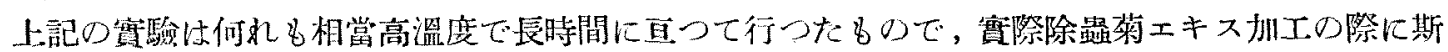

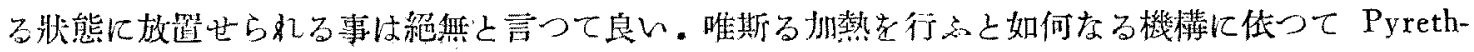

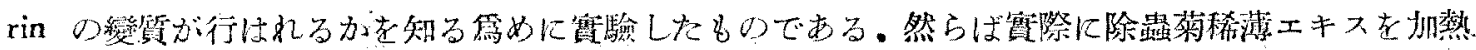

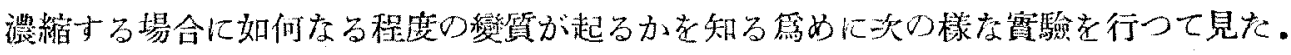

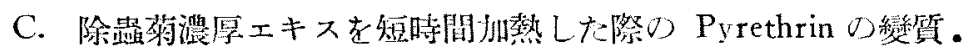

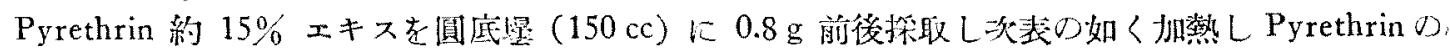

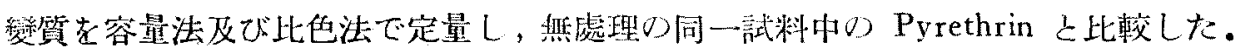

\begin{tabular}{|c|c|c|c|c|c|c|}
\hline & \multicolumn{4}{|c|}{ Pyrethrin \% (容 量 法) } & \multicolumn{2}{|c|}{ Pyrethrins \% (比色法) } \\
\hline & I & II & $\mathrm{I}+\mathrm{II}$ & 第筫 $(\%)$ & $\mathrm{I}+\mathrm{II}$ & 楍質 $(\%)$ \\
\hline 無 處 理 & 6.31 & 8.28 & 14.59 & 0 & 14.62 & 0 \\
\hline $90^{\circ}, 3$ 時間加熱 & 6.25 & 8.49 & 14.74 & -1.03 & 14.51 & 0.75 \\
\hline $90^{\circ}, 5$ 時間加熟 & 5.86 & 8.26 & 14.12 & 3.22 & 14.40 & 1.50 \\
\hline
\end{tabular}

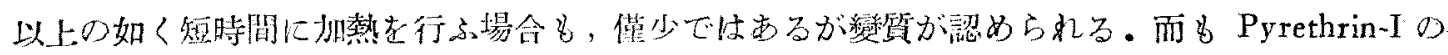
變貿は Pyrethrin-II の變質に較べると大であるが，此の際生成せられた二㿼基性酸，Oxy 酸乃至 は Keton 酸等が第二菊酸よして定量せられて Pyrethrin-II に算入せられる事は前述の寛驗と同様 に荟へて良い。

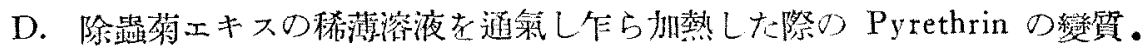

Pyrethrin 約 $20 \%$ エキ又 $5.0000 \mathrm{~g}$ 老圆底嚗 $(300 \mathrm{cc})$ に採取し，不油ベンジン（沸點 $100 \sim 120^{\circ}$ )

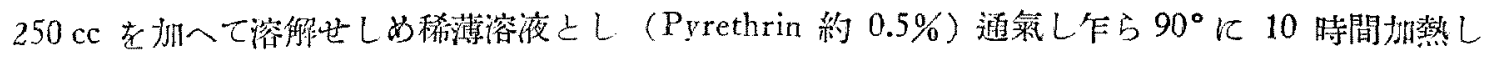

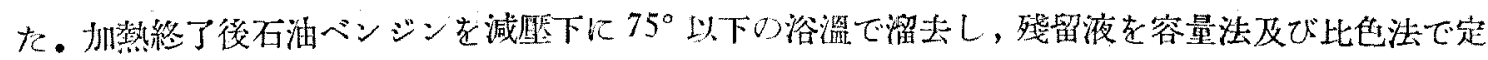
量し, 加熱せ奴同一試料と比較した。 


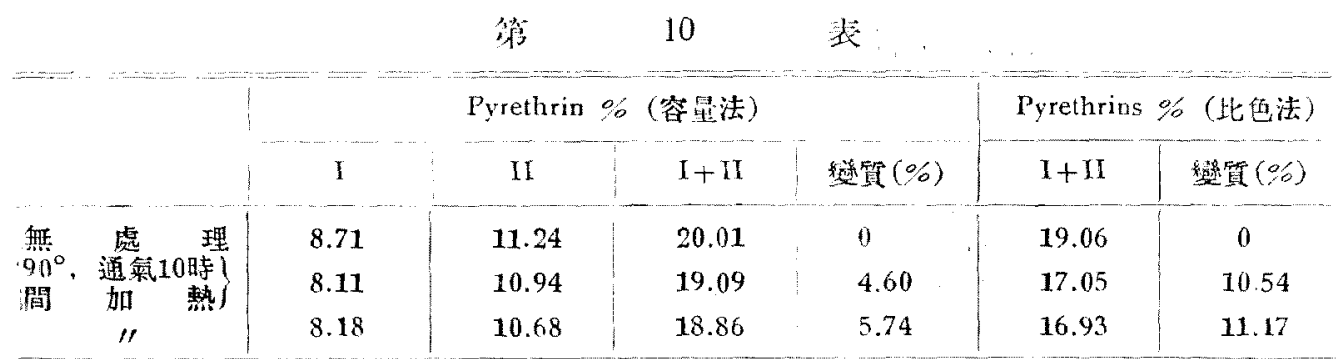

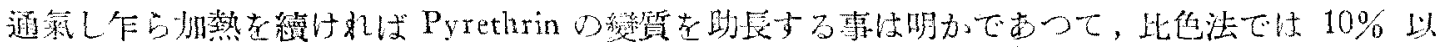

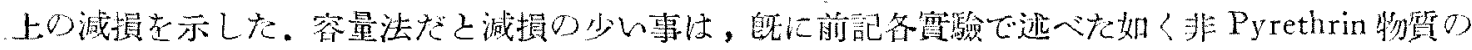

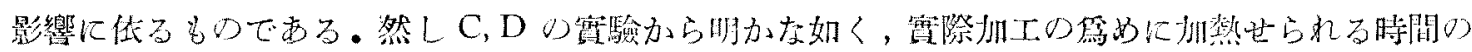

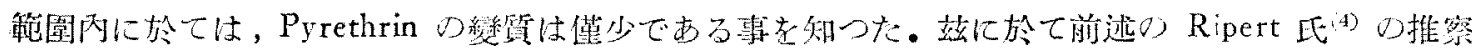

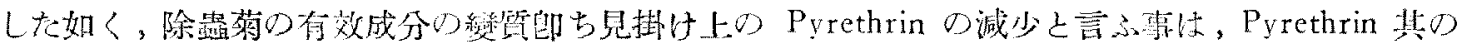

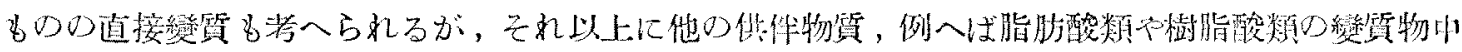

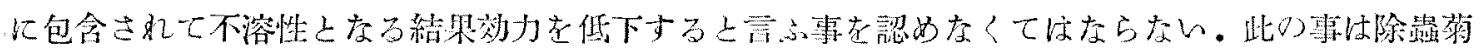

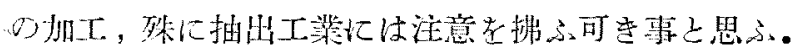

\section{結 諭}

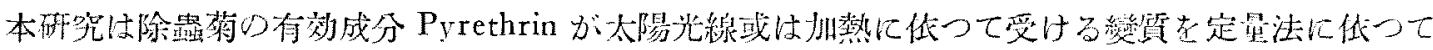

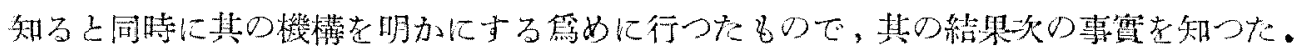

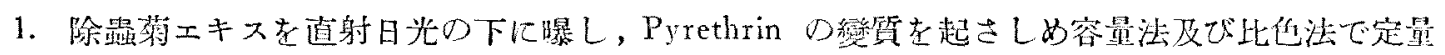

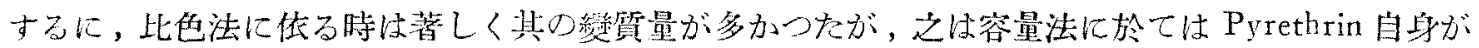

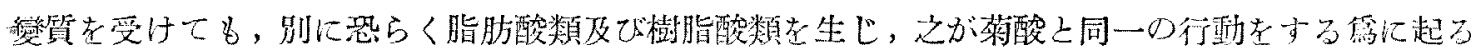
多のである事在知つた. Pyrethrin-II が Pyrethrin-I と並行に變質すると假定して，Pyrethrin-I

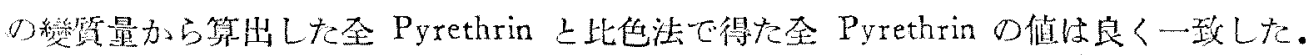

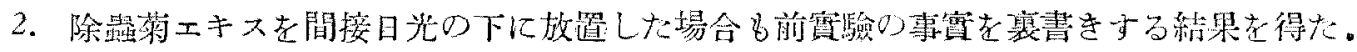

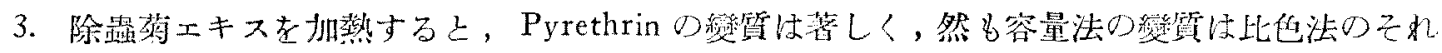
上り多かつた。 Pyrethrin-I の變留量加ら筑出した全 Pyrethrin と比色法で得た全 Pyrethrin とは

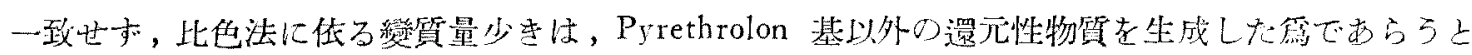
思忧る。

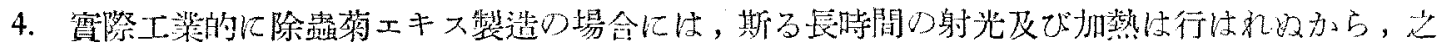

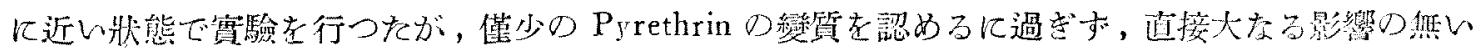

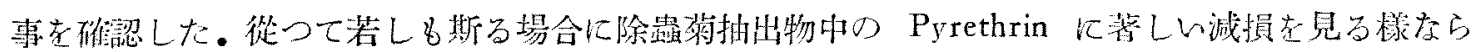

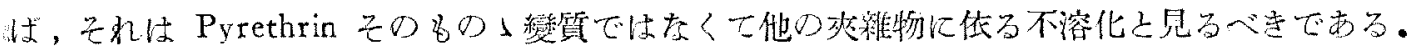

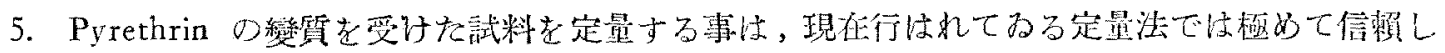

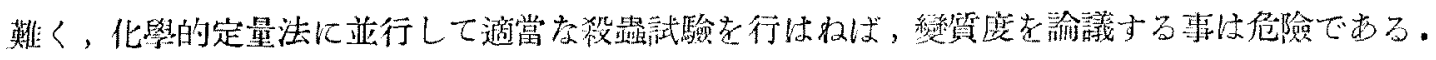




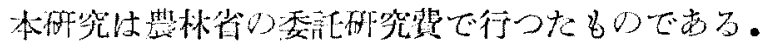

\section{交獻}

(1) Ablott, W. S.: U. S, Dept. Agr. Bull., 771, 1 8, (1919)

(2) Hartzell, A, and Wilcoxon, F.: Contrib. Boyce Thomp. Inst, 4, No, 1, 107 17 (1932)

(3) Gaadinger, C. B. "Pyrethrum Flowers", 2 nd Ed. P. 156

(4) Ripert, J.: Ann. fals., 27, 580 95, (1934)

28, $27 \sim 38,(1935)$

（5）武居三吉，若園橴：譬化，16，399，(1940）

(6) Tattersfe'd, F. and Martin, J. T. : J. Agr. Sci, 24, 598 (1934) 